\title{
STRATEGI BUDIDAYA IKAN KOKI BASTER (Carasius Auratus) RAMAH LINGKUNGAN DALAM UPAYA MENINGKATAN PRODUKSI
}

\author{
Susanti Mariam 1 \\ Eddy Supriyono 2 \\ Lina Warlina ${ }^{3}$ \\ 1)Dinas Kelautan dan Perikanan, Kab. Sukabumi \\ 2)Institut Pertanian Bogor \\ 3)Universitas Terbuka \\ e-mail: susanti.mariam@gmail.com
}

\begin{abstract}
Koki baster fish (Carasius auratus) or goldfish, besides as ornamental fish are also used as fish feed and fishing bait which demand tends to increase from year to year. However, from 2012 to 2015, the production of koki baster fish has decreased. This study aims to analyze the application of the management of koki baster fish in Cisaat Subdistrict, Sukabumi Regency, so that a management strategy can be formulated in developing environmentally friendly koki baster in Sukabumi Regency. Data collection was conducted through interviews, observations, questionnaires and documentation. The questionnaires were distributed to 100 respondents who were conducting hatchery for koki baster that scattered in 13 villages in Cisaat Subdistrict. As comparative data, the hatchery of koki baster fish was conducted in the research pond. The variables used are the aquaculture stage (x) consisting of lime dosage, organic fertilizer, anorganic fertilizer, water height, female parent, parent feed, comparison of male and female parent, parent age, larvae feed and duration to number of larvae (y). The variables were analyzed by validity, reliability, multiple regression analysis and principal component analysis using SPSS and Minitab application. Based on the results of multiple regression analysis obtained the relationship between variables in the seeding stage with the number of larvae. Correlation test showed that the variable use of fertilizers had a positive correlation of $69,5 \%$ to the number of larvae. Conversely, the variable water height has a negative value on the number of larvae, which is $-3.5 \%$. The principal component analysis showed that the variable use of organic fertilizer, anorganic fertilizer and larvae feed was in the first component area. It means that the variable has a large correlation to the number of larvae. The conclusion of there search is the community does not yet have standard in managing fish hatching of koki baster fish, they only rely on experience and habits so that the obtained production is still low. Strategies to increase the production of koki baster fish are need to be standardized on how to farm koki baster fish, standarized koki baster fish and community coaching on the need to carry out the stages of koki baster fish breeding in accordance with the good and environmentally friendly method of fish hatchery.
\end{abstract}

Keywords: koki baster fish, production improvement strategy, aquaculture stages, environmentally friendly 


\begin{abstract}
ABSTRAK
Ikan koki baster (Carasius auratus) selain sebagai ikan hias juga digunakan sebagai pakan ikan dan umpan pancing yang permintaannnya cenderung meningkat dari tahun ke tahun. Namun demikian dari tahun 2012 hingga 2015, produksi ikan baster mengalami penurunan. Penelitian ini bertujuan menganalisa penerapan manajemen usaha budidaya ikan koki baster di Kecamatan Cisaat Kabupaten Sukabumi sehingga dapat dirumuskan strategi pengelolaan dalam pengembangan budidaya ikan koki baster di Kabupaten Sukabumi yang ramah lingkungan. Pengumpulan data dilakukan melalui wawancara, pengamatan, kuesioner dan dokumentasi. Instrumen yang digunakan adalah kuesioner yang dibagikan kepada 100 orang responden yang melakukan kegiatan pembenihan ikan koki baster di 13 desa yang tersebar di Kecamatan Cisaat. Sebagai data pembanding dilakukan kegiatan pembenihan ikan koki baster di kolam penelitian. Variabel yang digunakan dalam analisis keterkaitan produksi adalah tahapan budidaya $(\mathrm{x})$ yang terdiri atas dosis kapur, pupuk organik, pupuk anorganik, tinggi air, induk betina, pakan induk, perbandingan induk jantan dan betina, umur induk, pakan larva, dan lama pemeliharaan terhadap jumlah larva (y). Variabel-variabel tersebut dianalisis dengan regresi berganda dan analisa komponen utama menggunakan aplikasi SPSS dan Minitab yang sebelumnya dilakukan uji validitas dan reliabilitas. Berdasarkan hasil analisa regresi berganda diperoleh keterkaitan antara varibael-variabel dalam tahapan pembenihan dengan jumlah larva. Uji korelasi menunjukan variabel penggunaan pupuk berkorelasi positif sebesar $69,5 \%$ terhadap jumlah larva. Sebaliknya variabel tinggi air memiliki nilai korelasi negatif terhadap jumlah larva yaitu sebesar $-3,5 \%$. Analisa komponen utama menunjukan bahwa variabel penggunaan pupuk organik, pupuk anorganik dan pakan larva berada pada wilayah first component artinya variabel tersebut memiliki korelasi yang besar terhadap jumlah larva. Kesimpulan dari penelitian ini adalah masyarakat belum memiliki standar dalam melaksanakan pengelolaan pembenihan ikan koki baster, hanya mengandalkan pengalaman dan kebiasaan saja sehingga produksi yang diperoleh masih rendah. Strategi untuk meningkatkan produksi ikan koki baster di masyarakat, perlu adanya standar tentang cara budidaya ikan koki baster, standardisasi ikan koki baster dan pembinaan kepada masyarakat tentang perlunya melaksanakan tahapan-tahapan budidaya ikan koki baster sesuai dengan cara pembenihan ikan yang baik dan ramah lingkungan.
\end{abstract}

Kata Kunci: ikan koki baster, strategi peningkatan produksi, tahapan-tahapan budidaya, ramah lingkungan

Produksi ikan koki baster di Kabupaten Sukabumi pada tahun 2015 baru memenuhi permintaan pasar sebesar 25\%.Berdasarkan data dari Dinas Kelautan dan Perikanan Kabupaten Sukabumi bahwa produksi ikan koki baster dari tahun 2011 sampai 2012 mengalami peningkatan sebesar 33\%, tetapi dari tahun 2012 sampai 2015 jumlah produksinya mengalami penurunan ratarata $6,7 \%$ per tahun (Bidang Perikanan Budidaya, 2015). Pada tahun 2015 produksi ikan koki baster di Kabupaten Sukabumi sebesar 58.058 ribu ekor dengan jumlah pembenih sebanyak 193 orang. Produksi ditargetkan meningkat sebanyak $5 \%$ pada setiap tahunnya. Diduga budidaya ikan koki baster di Kecamatan Cisaat belum ramah lingkungan, karena budidaya belum memperhatikan jumlah penggunaan kapur, pupuk dan pakan yang sisanya kemungkinan akan mencemari air dan tanah kolam. 
Kecamatan Cisaat merupakan salah satu kecamatan yang terdapat di Kabupaten Sukabumi dan merupakan penghasil ikan koki baster terbesar di Kabupaten Sukabumi. Produksi ikan koki baster dari Kecamatan Cisaat pada tahun 2015 sebesar 47.270 ribu ekor atau sebesar $81,42 \%$ dari total produksi ikan koki baster di Kabupaten Sukabumi yang berjumlah 58.058 ribu ekor (Bidang Perikanan Budidaya, 2015). Kecamatan Cisaat mempunyai iklim, cuaca dan kualitas air yang mendukung untuk pengembangan ikan koki baster di Kabupaten Sukabumi.

Kendala yang menyebabkan tidak tercapainya target produksi adalah karena terdapat keterbatasan teknologi dan keterampilan yang dimiliki pembudidaya, serta belum adanya standar untuk budidaya ikan koki baster. Selain itu, kajian tentang cara budidaya ikan koki baster masih sedikit sehingga sulit untuk mencari pedoman bagi budidaya ikan koki baster.

Ikan koki baster dipijahkan secara alami, sehingga memerlukan penanganan induk maupun benih yang baik, manajemen pemberian pakan dan pemantauan kualitas air untuk mendapatkan hasil yang optimum. Kualitas air yang diperlukan untuk budidaya ikan adalah $\mathrm{pH} 7$ dengan suhu air antara $27^{\circ}-30^{\circ} \mathrm{C}$ (Marbun, Darma, \&Nurmatias, 2013). Pakan merupakan faktor yang sangat penting diperhatikan untuk keberhasilan usaha budidaya ikan. Makanan ikan berfungsi sebagai sumber energi yang digunakan untuk pemeliharaan tubuh, pengganti jaringan tubuh yang rusak, pertumbuhan, aktifitas dan reproduksi (Mulyadi, Usman, \&Suryani, 2010).

Pertumbuhan ikan dapat dirumuskan sebagai pertambahan ukuran panjang atau berat dalam satuan waktu, sedangkan pertumbuhan populasi adalah pertambahan jumlah (Effendie, 1997). Menurut Huet (1986) pertumbuhan ikan dipengaruhi oleh faktor internal (faktor genetik, umur, jenis kelamin dan daya tahan tubuh) dan faktor eksternal (pakan, oksigen terlarut, suhu dan $\mathrm{pH}$ ). Ikan koki baster yang siap panen panjang tubuhnya sekitar $3-5 \mathrm{~cm}$, sedangkan induknya sekitar $10 \mathrm{~cm}$ dengan berat \pm 100 gram.

Mengingat produksi ikan koki baster masih tergolong sangat rendah (25\%) dibandingkan dengan jumlah permintaannya yang makin meningkat dari tahun ke tahun, dan potensi budidaya ikan koki baster masih dapat dikembangkan maka perlu diupayakan strategi yang efektif dalam pengembangannya. Maka perlu dilakukan penelitian yang tujuannya secara umum adalah menganalisa budidaya ikan koki baster di Kecamatan Cisaat Kabupaten Sukabumi. Hasil dari penelitian ini berupa perumusan strategi untuk budidaya ikan koki baster yang ramah lingkungan di Kabupaten Sukabumi.

\section{METODE}

Penelitian menggunakan desain penelitian survey yang menggunakan teknik pengumpulan data melalui wawancara, pengamatan, angket/kuesioner dan dokumentasi. Selain itu, juga melakukan kegiatan budidaya ikan dalam kondisi optimum yang akan dijadikan pembanding dengan hasil yang diperoleh dari masyarakat dengan cara melakukan budidaya ikan koki baster di tiga kolam percobaan. Instrumen penelitian yang dianalisa meliputi aspek kepemilikan lahan, persiapan kolam, sumber air, manajemen induk, manajemen pakan, pemijahan, kualitas air, jumlah produksi, kelimpahan pakan alami dan pemasaran.

Responden adalah para pembenih ikan koki baster yang berada di Kecamatan Cisaat. Hanya para pembenih yang dijadikan sampel karena mereka melakukan kegiatan sampai ukuran sekitar 14-20 hari sehingga waktu yang dibutuhkan tidak terlalu lama. Disamping itu, para pembenih melakukan kegiatan secara monokultur sehingga aspek-aspek yang diteliti dapat lebih fokus dibandingkan jika wawancara dilakukan kepada pendeder yang melakukan kegiatan secara polikultur sehingga permasalahannya lebih kompleks. Responden berjumlah 100 orang yang tersebar di 13 
lokasi yaitu Desa Kutasirna, Desa Selajambe, Desa Sukaresmi, Desa Cibolangkaler, Desa Nagrak, Desa Sukamantri, Desa Babakan, Desa Padaasih, Desa Cibatu, Desa Sukasari, Desa Sukamanah, Desa Cisaat dan Desa Gunungjaya.

Data yang dianalisis pada penelitian berasal dari 2 sumber yaitu data rekapitulasi dari responden dan data yang berasal dari hasil penelitian di kolam budidaya. Data yang diperoleh kemudian dibandingkan dengan melihat input dan output yang dihasilkan. Input dari responden berupa tahapan-tahapan yang biasa dilakukan masyarakat diantaranya persiapan kolam, induk, pakan dan kualitas air dibandingkan dengan data yang berasal rekapitulasi tahapan-tahapan budidaya yang dilakukan di kolam penelitian. Output dari responden berupa jumlah ikan yang dihasilkan oleh pembudidaya juga dibandingkan dengan output yang dihasilkan di kolam budidaya. Perbedaan yang ada kemudian dianalisis untuk memperoleh kesimpulan faktor-faktor apa saja di pembudidaya yang belum dan harus dilakukan untuk meningkatkan jumlah produksi budidaya.

\section{HASIL DAN PEMBAHASAN}

Dari 19 pertanyaan dalam kuesioner terdapat 16 pertanyaan yang bernilai valid pada tingkat signifikansi $\alpha=0,05$, dimana pada pertanyaan tersebut diperoleh nilai Sig. (1-tailed) $<0,05$. Tiga soal bernilai tidak valid pada tingkat sigifikansi $\alpha=0,05$ (nilai Sig. (1-tailed) $>0,05$ ) yaitu variabel ketinggian air, perbandingan induk jantan dan betina serta umur induk yang dipijahkan. Hal ini terjadi karena pemahaman masyarakat terhadap hubungan antara ketinggian air, perbandingan induk jantan dan betina serta umur induk yang dipijahkan terhadap produktivitas belum memadai.

Hasil uji reliabilitas (Koefisien Cronbach Alpha) menunjukan nilai sebesar 0,571 hampir mendekati batas nilai 0,60 (Pramesti, 2015). Hal ini menunjukkan jawaban responden terhadap tahapan-tahapan dalam pembenihan belum memiliki standar yang baku. Ketinggian air yang digunakan oleh para pembudidaya berbeda-beda tergantung pada jumlah ketersediaan air dan topografi kolam. Perbandingan jumlah induk jantan dan betina serta umur induk yang digunakan tidak berdasarkan jumlah yang seharusnya tetapi lebih berdasarkan pada jumlah induk yang tersedia dan siap memijah saja.

Hasil analisa regresi berganda terhadap kuesioner yang diberikan pada responden dapat dilihat pada Tabel 1.

Tabel 1. Hasil Analisis Regresi Berganda

\begin{tabular}{|c|c|c|c|c|c|c|}
\hline \multicolumn{7}{|c|}{ Coefficients ${ }^{\mathrm{a}}$} \\
\hline \multirow{2}{*}{\multicolumn{2}{|c|}{ Model }} & \multicolumn{2}{|c|}{ Unstandardized Coefficients } & \multirow{2}{*}{$\begin{array}{c}\begin{array}{c}\text { Standardized } \\
\text { Coefficients }\end{array} \\
\text { Beta }\end{array}$} & \multirow[b]{2}{*}{$\mathrm{t}$} & \multirow[b]{2}{*}{ Sig. } \\
\hline & & B & Std. Error & & & \\
\hline \multirow[t]{11}{*}{1} & (Constant) & 78575.804 & 53221.864 & & 1,476 & 0,143 \\
\hline & dosis_kapur & 66218.096 & 236885.447 & 0,018 & 0,280 & 0,780 \\
\hline & pupuk_org & 108517.149 & 46363.071 & 0,151 & 2,341 & 0,021 \\
\hline & pupuk_anorg & 5670281.485 & 773317.520 & 0,522 & 7,332 & 0,000 \\
\hline & tinggi_air & -106.534 & 216.038 & $-0,032$ & -0493 & 0,623 \\
\hline & induk_betina & 478.532 & 63.604 & 0,494 & 7,524 & 0,000 \\
\hline & Pakan_induk & -535.741 & 2916.983 & $-0,013$ & $-0,184$ & 0,855 \\
\hline & Perbandingan & -25683.344 & 12900.205 & $-0,127$ & -1.991 & 0,050 \\
\hline & Umur_induk & 798.176 & 997.971 & 0,049 & 0,800 & 0,426 \\
\hline & Pakan_larva & 9881.086 & 5513.344 & 0,118 & 1,792 & 0,076 \\
\hline & lama_pemel & 125.913 & 1345.978 & 0,006 & 0,094 & 0,926 \\
\hline
\end{tabular}

a. Dependent Variable: Jumlah_larva 
Berdasarkan hasil analisa regresi berganda diperoleh persamaan sebagai berikut: Jumlah larva $=78575.804+66218.096$ dosis kapur +108517.149 pupuk org +5670281.485 pupuk anorg - 106.534 tinggi air +478.532 induk betina -535.741 pakan nduk -25683.344 perbandingan induk jantan dan betina +798.176 umur induk +9881.086 pakan larva +125.913 lama pemeliharaan.

Hasil uji korelasi antara variabel $Y$ (jumlah larva) dengan variabel $X$ (tahapan budidaya, yaitu: dosis kapur, pupuk organik, pupuk anorganik, tinggi air, induk betina, pakan induk, perbandingan induk jantan betina, umur induk, pakan larva dan lama pemeliharaan) dapat dilihat pada Tabel 2.

Tabel 2. Uji Korelasi Antara Variabel Y (jumlah larva) dengan Variabel X (Tahapan Budidaya) pada Tingkat Kepercayaan 5\%

\begin{tabular}{lccl}
\hline \multicolumn{1}{c}{ Variabel } & Nilai $\mathrm{r}(\mathrm{x})$ & Nilai sig $(\mathrm{x})$ & Hipotesis \\
\hline Pengeringan kolam & Konstan & & $\mathrm{H}_{0}$ ditolak \\
Perbaikan kolam & Konstan & & $\mathrm{H}_{0}$ ditolak \\
Pengapuran & 0,306 & 0,002 & $\mathrm{H}_{0}$ ditolak \\
Dosis pupuk organik & 0,337 & 0,001 & $\mathrm{H}_{0}$ ditolak \\
Dosis pupuk anorganik & 0,695 & 0,000 & $\mathrm{H}_{0}$ ditolak \\
Ketinggian air & $-0,035$ & 0,730 & $\mathrm{H}_{0}$ diterima \\
Jumlah induk betina & 0,486 & 0,000 & $\mathrm{H}_{0}$ ditolak \\
Jumlah pakan induk & 0,262 & 0,008 & $\mathrm{H}_{0}$ ditolak \\
Perbandingan induk jantan dan betina & $-0,116$ & 0,249 & $\mathrm{H}_{0}$ diterima \\
Umur induk yang dipijahkan & 0,039 & 0,698 & $\mathrm{H}_{0}$ diterima \\
Jumlah pakan larva & 0,452 & 0,000 & $\mathrm{H}_{0}$ ditolak \\
Lama pemeliharaan larva & 0,079 & 0,437 & $\mathrm{H}_{0}$ diterima \\
\hline
\end{tabular}

$\mathrm{H}_{0}: \rho=0$ (tidak ada korelasi antara variabel y dan variabel $\mathrm{x}$ )

$\mathrm{H}_{1}: \rho \neq 0$ (ada korelasi antara variabel y dan variabel $\mathrm{x}$ )

Tingkat signifikansi $\alpha=5 \%=0,05$

Analisa komponen utama terhadap hasil wawancara dapat dilihat pada Tabel 3 .

Tabel 3. Hasil Analisa Komponen Utama

\section{Principal Component Analysis: Dosis kapur; Pupuk organi; Pupuk an org; Tinggi air; Induk beti}

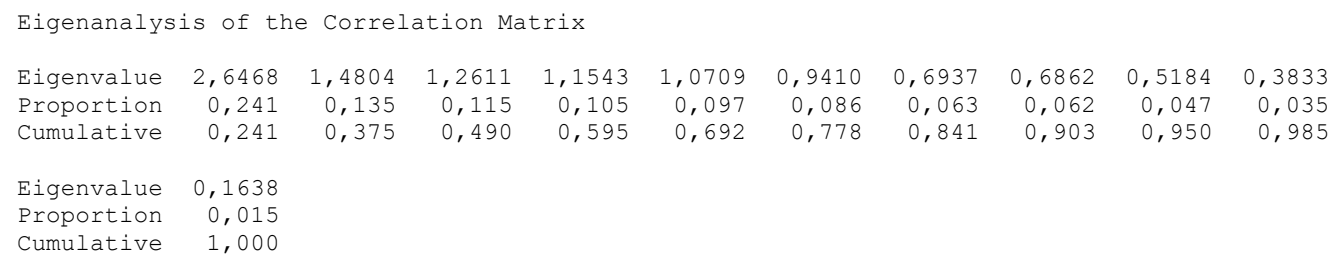




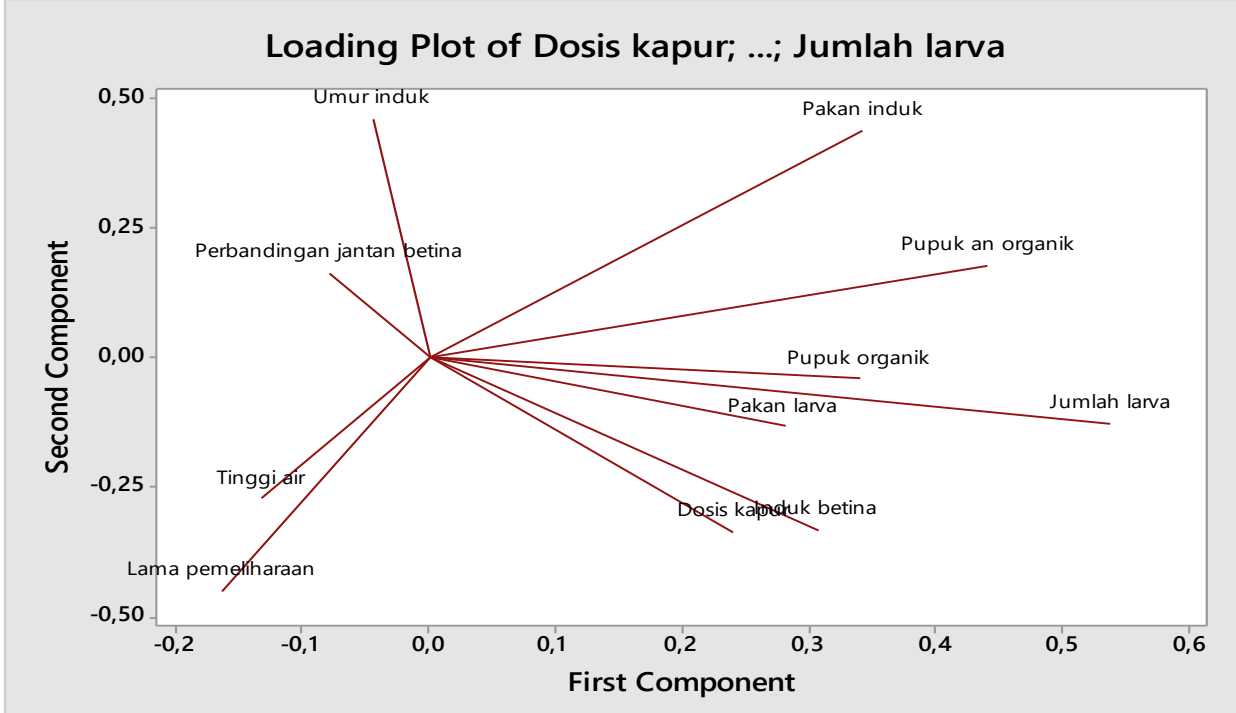

Gambar 1. Plot loading variabel bebas dan variabel terikat

Hasil analisa regresi berganda ditemukan bahwa terdapat keterkaitan antara varibel-variabel dalam tahapan pembenihan dengan jumlah larva. Berdasarkan persamaan regresi pada Tabel 1 koefisien regresi untuk variabel pupuk anorganik memiliki nilai positif yaitu sebesar 5670281.485 artinya pada saat jumlah penggunaan pupuk anorganik naik maka jumlah larva juga akan mengalami kenaikan.

Berdasarkan uji korelasi bahwa variabel $\mathrm{X}$ (tahapan budidaya) sebagian besar berkorelasi positif terhadap jumlah larva, sehingga ketika pembenih menerapkannya pada kegiatan budidaya maka jumlah produksi akan meningkat. Dosis pupuk berkorelasi positif terhadap produksi yaitu sebesar $69,5 \%$. Sebagian besar pembenih melakukan pemupukan walaupun dengan dosis yang belum sesuai ketentuan. Hal ini dilakukan karena kesadaran masyarakat terhadap pentingnya pemupukan yang sesuai ketentuan masih rendah. Namun demikian, dosis ini harus benar-benar diperhitungkan agar tidak ada limbah ataupun kelebihan dari pupuk tersebut, khususnya pupuk anorganik yang akan berdampak terhadap lingkungan. Pembudidaya harus tepat dalam memberikan dosis pupuk, sebab dosis yang berlebih akan terbuang larut dalam aliran air, sehingga akan menyebabkan terjadinya pencemaran terhadap air dan tanah kolam pemijahan.

Pada Gambar 1 terlihat bahwa variabel yang berkorelasi besar terhadap jumlah larva adalah penggunaan pupuk dan ketersediaan pakan. Hal ini menunjukkan bahwa kedua faktor tersebut merupakan hal yang berkaitan erat dengan peningkatan produksi sehingga masyarakat harus diberi pemahaman tentang hal tersebut dan mau menerapkannya pada kegiatan budidaya ikan koki baster. Seperti halnya dosis pupuk yang harus tepat, dosis pemberian pakan juga demikian, karena kelebihan pakan akan mencemari air dan tanah kolam pemijahan.

Variabel ketinggian air dan perbandingan induk jantan betina memiliki nilai korelasi yang rendah yaitu sebesar $3,5 \%$ dan $11,6 \%$. Hasil analisa regresi berganda pada variabel tinggi air 106.534 dan perbandingan induk jantan betina -25683.344 . Berdasarkan grafik hasil analisa komponen utama kedua variabel tersebut berada pada wilayah second component. Tidak ada 
standar di masyarakat dalam penggunaan ukuran ketinggian air menyebabkan perbedaan jumlah produksi larva yang dihasilkan. Ketinggian kolam air budidaya berhubungan dengan suhu perairan.

Semua responden melakukan pengeringan sebelum dimulai kegiatan pembenihan. Hal ini menunjukkan adanya kesadaran pembudidaya tentang pentingnya proses pengeringan untuk membunuh kuman penyakit dan mengoksidasi bahan organik yang dapat meracuni ikan. Pengeringan dilakukan selama kurang lebih 2-5 hari tergantung pada kondisi cuaca. Tahap kedua setelah pengeringan adalah perbaikan kolam. Sama halnya dengan pengeringan, perbaikan kolam dilakukan oleh semua responden pada setiap kolam. Hal ini dilakukan untuk menghindari terjadinya kebocoran kolam ketika ikan dipelihara. Setelah kolam kering dan diperbaiki, dilakukan pemberian kapur untuk membasmi hama. Jumlah kapur yang diberikan sangat beragam, sebagian besar responden menggunakan kapur dengan dosis sebesar $1-15 \mathrm{gr} / \mathrm{m}^{2}$ sebanyak $46 \%$. Pemupukan bertujuan untuk mempertahankan kestabilan keasaman $(\mathrm{pH})$ tanah dan air, memberantas hama penyakit di kolam budidaya. Pemupukan dilakukan oleh sebagian responden saja, sebanyak $64 \%$ tidak melakukan pemupukan karena mereka beranggapan air yang mengalir ke kolam mengandung cukup banyak jasad renik yang diperlukan larva ketika masa kuning telur habis. Padahal pada kenyataannya air yang masuk ke kolam budidaya diduga sudah menurun kualitasnya karena tercemar oleh limbah rumah tangga akibat banyaknya pemukiman di sekitar kolam budidaya. Hal ini akan berdampak pada pertumbuhan dan jumlah produksi ikan karena pada fase kritis ikan akan kekurangan nutrisi akibat kurangnya supplai pakan yang berasal dari perairan.

Sebanyak $56 \%$ responden tidak memberikan pupuk anorganik pada kolam mereka. Hal ini dilakukan dengan alasan yang sama seperti pada pemberian pupuk organik, mereka hanya mengandalkan asupan nutrisi untuk larva mereka dari jasad renik yang ada di perairan. Frekuensi pemupukan dilakukan sebanyak 1 (satu) kali setiap setelah panen. Ketinggian air kolam berkisar antara 60-80 sebesar dilakukan oleh $58 \%$ responden.

Sebanyak 69\% responden memijahkan induk betina kurang dari 100 ekor setiap kali pemijahan. Kepemilikan induk sangat dipengaruhi modal setiap responden. Rata-rata responden memiliki induk sekitar 200 ekor. Rentang waktu induk dapat memijah kembali adalah 2 (dua) bulan sampai telur siap dibuahi sehingga untuk responden yang hanya memiliki induk sekitar 200 ekor, kemungkinan hanya dapat memijahkan ikannya setiap satu bulan sekali. Selain terbatasnya jumlah induk yang dimiliki, kepemilikan kolam juga menjadi faktor pembatas dalam kegiatan pembenihan. Responden yang tidak memiliki banyak kolam biasanya akan menyimpan induk jantan dan betina secara bersamaan dalam satu kolam. Hal ini rentan terjadinya ikan memijah secara liar, karena kokibaster merupakan tipe ikan yang mudah memijah. Tentu saja jika kondisi ini terjadi akan merugikan pembudidaya karena ketika waktu pemijahan tiba induk sebagian sudah tidak bertelur, sehingga jumlah produksi larva akan menurun.

Berdasarkan data hasil wawancara, setiap hari induk yang akan dipijahkan diberi pakan dengan jumlah kurang dari $1 \mathrm{~kg} / \mathrm{hari}$ (sebanyak $76 \%$ responden). Idealnya pemberian pakan induk adalah sebesar $30 \%$ dari biomassa induk baster. Menurut Woynarovich dan Horvath dalam Huwoyon, Ningrum, \& Aditiya (2011) kualitas dan jumlah pakan mempunyai peranan penting bagi pematangan gonad dalam menghasilkan telur dengan kualitas baik (daya tetas tinggi). Sebanyak 95\% responden memijahkan induk koki baster dengan perbandingan $3: 1$. Induk yang dipijahkan berumur $10-15$ bulan, kisaran umur ini digunakan responden sebanyak $57 \%$.

Pengamatan kualitas air tidak dilakukan oleh 93\% responden. Hal ini disebabkan karena sebagian besar pembudidaya tidak memiliki alat untuk menguji kualitas air. Hanya sebagian kecil saja yang memiliki alat untuk menguji kualitas air padahal mereka menyadari perlunya pemeriksaan 
kualitas air terlebih ketika musim penghujan dimana pada saat tersebut suhu, $\mathrm{pH}$ dan parameter lainnya akan mengalami perubahan yang ekstrim dan perlu perlakuan untuk menjaga supaya kondisi perairan cenderung stabil. Oleh karena itu pembudidaya hanya melakukan pengujian secara manual seperti melakukan pengamatan terhadap warna air.

Menurut para responden warna kolam air rata-rata adalah hijau. Hal ini terjadi pada kolam responden sebanyak $97 \%$. Sebanyak $77 \%$ responden memberikan pakan berupa pelet untuk larva baster. Sisanya diberi dedak (sebanyak 22\%) dan 1\% tidak diberi pakan. Jumlah pakan yang diberikan adalah $1 \mathrm{~kg} / \mathrm{hari}(56 \%)$ dengan frekuensi 1 kali per hari (53\%). Produksi yang dihasilkan adalah 60.000-100.000 ekor (sebanyak 37\%) sisanya adalah kurang dari 50.000 ekor sebanyak $32 \%, 160.000-200.000$ ekor sebanyak 18\%, 110.000-150.000 sebanyak $18 \%$ dan lebih dari 200.000 ekor sebanyak 1\%. Panen larva dilakukan setelah 20 (dua puluh hari) masa pemeliharaan larva. Distribusi larva adalah ke pasar lokal, dimana larva akan disebar kepada para pendeder yang berada di wilayah Kecamatan Cisaat dan sekitarnya.

Rincian kegiatan budidaya ikan koki baster di kolam penelitian diperoleh hasil sebagaimana Tabel 4.

Tabel 4. Data Hasil Penelitian Di Kolam Budidaya

\begin{tabular}{lccc}
\hline \multicolumn{1}{c}{ Uraian } & Kolam 1 & Kolam 2 & Kolam 3 \\
\hline Pengeringan (kali) & 1 & 1 & 1 \\
Perbaikan kolam (kali) & 1 & 1 & 1 \\
Pemberian kapur (gr/m²) & 50 & 50 & 50 \\
Pemberian pupuk organik (gr/m²) & 300 & 275 & 250 \\
Ketinggian air (cm) & $60-80$ & $60-80$ & $60-80$ \\
Induk betina yang dipijahkan (ekor) & 150 & 150 & 150 \\
Pakan induk (kg) & 1,5 & 1,5 & 1,5 \\
Perbandingan jumlah induk Ō dan + (ekor) & $400: 150$ & $400: 150$ & $400: 150$ \\
Umur induk yang dipijahkan (bulan) & $8-12$ & $8-12$ & $8-12$ \\
Warna Air & Hijau pekat & Hijau pekat & Hijau pekat \\
Jenis pakan larva & Pelet & Pelet & Pelet \\
Jumlah pakan larva (kg) & 2 & 2 & 1,8 \\
Frekuensi pemberian pakan (kali/hari) & 2 & 2 & 2 \\
Produksi larva (ekor) & 250.000 & 250.000 & 190.000 \\
Lama pemeliharaan larva (hari) & 20 & 20 & 20 \\
Harga benih (Rp/ekor) & 12 & 12 & 12 \\
Distribusi & Sukabumi & Sukabumi & Sukabumi \\
& & & \\
\hline
\end{tabular}

Kegiatan pembenihan dilakukan di tiga kolam penelitian dimana hasil yang diperoleh dapat dilihat pada Tabel 4. Berdasarkan data pada Tabel 4 dapat dilihat bahwa kegiatan dimulai dengan melakukan pengeringan kolam selama 2-5 hari. Ketika kolam sedang dikeringkan, dilakukan perbaikan bagian pematang, dinding dan dasar kolam untuk mencegah terjadinya kebocoran. Kebocoran perlu dicegah untuk menjaga ketersediaan dan suhu air di kolam. Setelah dilakukan perbaikan, kolam diberi kapur dengan dosis $50 \mathrm{gr} / \mathrm{m}^{2}$ dan pemupukan dengan menggunakan pupuk organik sebanyak $250-300 \mathrm{gr} / \mathrm{m}^{2}$, selanjutnya diberi air sampai ketinggian $60-80 \mathrm{~cm}$. 
Tahap berikutnya adalah mempersiapkan induk yang akan dipijahkan. Pemeliharaan induk dilakukan pada kolam yang terpisah antara induk jantan dan betina untuk mencegah terjadinya pemijahan liar dan lebih memudahkan pada saat seleksi induk matang gonad.

Induk diberi pakan dengan frekuensi 2 (dua) kali sehari, yaitu sekitar pukul 09.00 WIB dan pukul 14.30 WIB. Frekuensi pemberian pakan ditentukan antara lain oleh spesies dan ukuran ikan serta faktor-faktor yang mempengaruhi napsu makan ikan (Tahapari \& Ningrum, 2009). Pada dasarnya ketiga faktor tersebut sangat berkaitan satu dengan yang lainnya. Makin kecil ukuran ikan, makin sering frekuensi pemberian pakan. Hal ini berhubungan dengan kapasitas dan laju pengosongan lambung, makin cepat waktu pengosongan lambung, frekuensi pemberian pakan yang dibutuhkan makin tinggi. Setelah terjadi pengurangan isi lambung, nafsu makan beberapa jenis ikan akan meningkat kembali. Dengan demikian frekuensi pemberian pakan untuk benih akan berbeda dengan ikan yang sudah dewasa. Pemberian pakan dilakukan sebanyak 2 (dua) kali sehari dan dilakukan pada pagi hari dan sore hari. Hal ini dimungkinkan karena sifat diurnal ikan yang sudah terbiasa merespon pakan yang diberikan pada jam-jam tersebut, dimana ikan akan berkumpul pada saat diberi pakan. Selain itu, pemberian pakan dengan frekuensi 2-3 kali sehari dimaksudkan untuk memenuhi kebutuhan pakan terutama protein yang diperlukan oleh ikan untuk mempercepat proses pematangan gonad. Pemberian pakan yang dibagi menjadi beberapa kali lebih efektif dikonsumsi ikan dibanding pemberian pakan langsung habis sebanyak 1 (satu) kali. Cara ini kurang efektif karena banyak pakan yang terbuang. Banyaknya pakan yang terbuang akan mencemari lingkungan sekitar.

Efek pemberian pakan telah diteliti oleh Hafeez-ur-Rehman et al. (2015),yang menyatakan bahwa pemberian frekuensi pakan memiliki efek mendalam pada pertumbuhan ikan koki baster. Namun frekuensi pemberian dua kali per hari lebih baik untuk mendapatkan berat badan maksimum tetapi efisiensi pakan bisa ditingkatkan jika frekuensi pakan tetap satu kali per hari. Apalagi untuk membesarkan ikan di tingkat komersial dianjurkan untuk ahli genetika dan peternak untuk meningkatkan potensi genetiknya. Selain itu, jenis pakan yang disukai ikan koki baster adalah pakan hidup daripada pakan buatan. Ikan baster memiliki tingkat konsumsi nyamuk larva yang jauh lebih tinggi daripada guppy dan Aplocheilus sp. Konsumsi makanan hidup ini dapat bermanfaat untuk mendapatkan pertumbuhan yang baik dan kelangsungan hidupnya (Gupta \& Banerjee, 2009).

Kegiatan seleksi induk bertujuan untuk mendapatkan induk yang matang gonad dan siap untuk memijah. Seleksi induk dilakukan dengan cara mengurangi ketinggian air kolam terlebih dahulu, hingga air yang tersisa pada bagian saluran air saja. Hal ini bertujuan untuk mempermudah penangkapan ikan. Selanjutnya induk diperiksa satu persatu berdasarkan ciri fisik tubuhnya. Induk yang diseleksi dan matang gonad diambil kemudian dipindahkan ke dalam kolam pemberokkan.

Kolam pemijahan diberi ijuk sebagai tempat menempelnya telur ketika proses pemijahan berlangsung. Perbandingan jantan dan betina adalah $3: 1$ dimana induk jantan lebih banyak daripada induk betina. Pada saat penelitian biasanya induk jantan dan betina mulai disatukan di kolam pemijahan pada pukul 09.00 WIB dan akan mulai memijah sekitar pukul 24.00 WIB sampai pukul 05.30 WIB. Pada pagi hari substrat akan dipenuhi oleh telur ikan koki baster. Pada pukul 08.00 induk akan diangkat untuk menghindari dimakannya telur-telur oleh induknya dan disimpan kembali di kolam induk untuk pemulihan sampai telurnya matang kembali. Setelah 3 (tiga) jam sejak induk diangkat dari kolam pemijahan, dilakukan pemberian pupuk dengan cara memasukkan pupuk kedalam karung kemudian diikat dan dimasukkan ke dalam kolam. Pemberian pupuk bertujuan untuk menumbuhkan pakan alami sehingga dapat mensuplai nutrisi bagi kelangsungan hidup larva. 
Pemberian pupuk dalam karung merupakan salah satu upaya agar pupuk tidak ada yang tersisa dan mencemari kolam.

Pemeliharaan larva dilakukan pada kolam yang sebelumnya digunakan sebagai kolam pemijahan. Telur akan menetas setelah 3 (tiga) hari dari masa pemijahan. Setelah menetas, 3 (tiga) hari kemudian atau 6 (enam) hari dari masa pemijahan larva mulai membutuhkan nutrisi karena cadangan kuning telur dalam tubuhnya telah habis. Pada masa tersebut ketersediaan plankton harus sudah siap agar ikan dapat memanfaatkan plankton yang ada di air. Untuk mencegah terjadinya kekurangan nutrisi ikan, pada saat larva berumur 10 hari ditambah dengan pemberian pelet tepung sesuai ketentuan.

Setelah larva berumur 17 hari dilakukan proses pemanenan. Pada umur tersebut panjang larva berada pada kisaran 1,78-2,26 cm dan berat sekitar 0,08- 0,17 gr/ekor. Jumlah ikan yang dihasilkan sebanyak 190.000 sampai 250.000 pada setiap. Perbedaan jumlah ikan yang dihasilkan terjadi karena jumlah induk yang dipijahkan berbeda-beda.

Untuk mengetahui kualitas air kolam, parameter yang diamati dalam penelitian adalah suhu, nilai $\mathrm{pH}$, kandungan oksigen dan alkalinitas. Data pengukuran suhu pada saat penelitian berkisar antara $24^{\circ} \mathrm{C}-26^{\circ} \mathrm{C}$. Kisaran ini ideal untuk pemeliharaan ikan koki baster, menurut Murtiati \&Yati (2016), suhu ideal untuk ikan budidaya berada pada kisaran $24^{\circ} \mathrm{C}-30^{\circ} \mathrm{C}$. Hasil pengukuran $\mathrm{pH}$ pada saat penelitian berkisar antara 6,3-7,57. Nilai ini masih dapat ditolerir oleh ikan koki baster karena masih berada pada kisaran $\mathrm{pH}$ netral.

Penelitian dampak suhu telah dilakukan oleh Fry \& Hart (2011), ketika ikan ditempatkan di ruang annular yang berputar dengan dinding luarnya adalah kaca, mereka dapat diinduksi untuk berenang dengan mantap pada tingkat yang bervariasi dengan suhu ketika air di angin-anginkan. Ketika ikan telah berada suhu eksperimental, suhu terbaik dicapai pada suhu 20 hingga $30^{\circ} \mathrm{C}$, suhu tertinggi di mana ikan dapat bertahan adalah $41^{\circ} \mathrm{C}$.

Kandungan oksigen di perairan harus juga diperhatikan karena akan berpengaruh terhadap pertumbuhan ikan koki baster. Menurut Murtiati \&Yati (2016) kandungan oksigen minimum 4 mg/liter, pada konsentrasi 1-3 mg/liter ikan dapat hidup tetapi tumbuh lambat. Kandungan oksigen < 1 $\mathrm{mg} /$ liter akan terjadi kematian secara massal. Data pengukuran kandungan oksigen di kolam penelitian berkisar antara 8,50-23,09. Nilai ini dianggap aman untuk tumbuh kembangnya ikan koki baster. Tingginya kandungan oksigen dapat dipengaruhi oleh proses fotosintesis dari tumbuhan air dan organisme akuatik lainnya yang menghasilkan oksigen serta proses difusi oksigen dari udara bebas.

Perairan yang mengandung alkalinitas $\geq 20$ ppm menunjukkan bahwa perairan tersebut relatif stabil terhadap perubahan asam/basa, sehingga kapasitas buffer atau basa lebih stabil. Nilai alkalinitas air kolam penelitian adalah 42,40-89,04 ppm, yang berarti nilai aman untuk pertumbuhan ikan koki baster.

Berdasarkan hasil analisis terhadap tahapan-tahapan dan faktor-faktor yang mempengaruhi jumlah produksi, adanya perbedaan jumlah produksi pada pembenihan di masyarakat dan di kolam penelitian disebabkan belum dilaksanakannya tahapan demi tahapan pembenihan yang baik di masyarakat. Pada persiapan kolam jumlah kapur dan pupuk yang diberikan masih rendah yaitu 1-15 $\mathrm{gr} / \mathrm{m}^{2}$. Rendahya pemberian kapur akan berpengaruh terhadap tingkat keasaman tanah sedangkan pupuk yang digunakan sebanyak $1-150 \mathrm{gr} / \mathrm{m}^{2}(31 \%), 0 \mathrm{gr} / \mathrm{m}^{2}(64 \%)$ untuk pupuk organik dan pupuk anorganik sebesar $1-6 \mathrm{gr} / \mathrm{m}^{2}(20 \%), 0 \mathrm{gr} / \mathrm{m}^{2}(56 \%)$. Jumlah pupuk yang diberikan kurang dari jumlah yang dianjurkan sebesar $100-500 \mathrm{gr} / \mathrm{m}^{2}$ dan pupuk anorganik sekitar $10 \mathrm{gr} / \mathrm{m}^{2}$ tergantung pada 
kesuburan tanah. Padahal pupuk berguna untuk menyuburkan perairan yang akan memacu pertumbuhan fitoplankton dan zooplankton yang berguna sebagai pakan alami ikan. Proses fotosintesis yang terjadi dalam air akan meningkatkan kadar oksigen sehingga bermanfaat juga untuk pertumbuhan ikan. Rendahnya jumlah pupuk yang digunakan menyebabkan perairan menjadi kurang subur dan plankton yang tumbuh di kolam budidaya rendah. Akibatnya ikan akan kekurangan nutrisi dan pertumbuhan tidak optimal. Namun demikian, pupuk yang diberikan secara berlebih juga akan mencemari lingkungan, karena itu dosis pemupukan sangat penting dalam proses budidaya ikan.

Faktor lain yang menyebabkan rendahnya jumlah produksi ikan koki baster di masyarakat diduga akibat terjadinya pemijahan liar induk-induk baster karena induk jantan dan betina tidak dipelihara secara terpisah. Selain itu kurang terawatnya bagian pematang kolam dimana ada sebagian tanaman yang menjulur ke kolam digunakan oleh induk baster sebagai tempat untuk menempelkan telur-telurnya. Pada saat musim penghujan induk-induk yang akan dipijahkan adakalanya menjadi sakit dan telur yang dihasilkan menjadi rendah. Perubahan suhu dan parameter kualitas air lainnya akan mengakibatkan ikan menjadi stres.

Kegiatan budidaya ikan koki baster dimulai dari tahap persiapan kolam. Jumlah kapur, pupuk organik dan anorganik yang diberikan harus sesuai dengan standar agar hasil yang diperoleh lebih optimal. Pemberian pakan sebaiknya dihitung berdasarkan biomassa ikan sehingga ikan tidak kekurangan nutrisi yang dibutuhkan untuk tumbuh dan kembangnya, dan juga tidak ada sisa kelebihan pakan yang akan mencemari lingkungan. Jumlah induk yang dipelihara hendaknya ditambah supaya proses pembenihan dapat berkesinambungan. Pola tanam dapat diatur dan panen dapat terus menerus dilakukan.

Seleksi dilakukan agar induk yang akan digunakan dalam proses budidaya berkualitas baik. Penambahan jumlah kolam diperlukan untuk menyediakan tempat bagi induk jantan dan betina secara terpisah. Kebersihan kolam dan lingkungan budidaya harus dipelihara untuk mencegah terjadinya pemijahan liar dan induk siap matang gonad ketika proses pemijahan berlangsung.

Curah hujan yang tinggi di kolam budidaya dapat diminimalisir dengan menggunakan shelter di bagian atas kolam induk untuk mencegah masuknya air hujan ke perairan yang akan menyebabkan perubahan suhu, pH dan kandungan oksigen secara ekstrim. Kedepannya untuk meningkatkan produksi budidaya ikan hias perlu adanya penerapan dan cara budidaya ikan yang terstandar yang merupakan bagian dari sistem pengendalian mutu hasil perikanan.

Terkait pengelolaan ikan yang ramah lingkungan, hal-hal yang harus diperhatikan dalam manajemen budidaya ikan adalah pengembangan pakan lokal, penggunaan probiotik, budidaya ikan dengan sistem akuaponik serta budidaya ikan secara terintegrasi (Syamsunarno \& Sunarno, 2016). Penggunaan pakan lokal yang sesuai standard dengan dosis yang tepat sangat dianjurkan, dan perlu dikembangkan terus karena selain berharga murah, juga terbukti dapat mengurangi limbah pakan dan feses di perairan. Dampak racun limbah pakan dan feses dapat ditekan dengan penambahan mikroba yang dikenal dengan probiotik. Budidaya ikan dengan menggunakan sistem akuaponik dimaksudkan untuk memanfaatkan limbah organic dari sisa pakan dan feses ikan yang merupakan unsur hara bagi berbagai tanaman. Sedangkan budidaya ikan secara terintegrasi adalah teknologi polikultur yang memanfaatkan sumber pakan alami yang tersedia di kolam dengan memelihara ikan yang mempunyai kebiasaan makan dan makanan yang berbeda.

\section{SIMPULAN}

Masyarakat belum memiliki standar dalam melaksanakan pengelolaan pembenihan ikan koki baster, hanya mengandalkan pengalaman dan kebiasaan saja sehingga produksi yang diperoleh 
masih rendah. Berdasarkan hasil analisa regresi berganda diperoleh keterkaitan antara varibaelvariabel dalam tahapan pembenihan dengan jumlah larva yang dihasilkan. Uji korelasi menunjukan variabel penggunaan pupuk berkorelasi positif sebesar $69,5 \%$ terhadap jumlah larva. Sebaliknya variabel tinggi air memiliki nilai negatif terhadap jumlah larva yaitu sebesar $-3,5 \%$. Analisa komponen utama menunjukan bahwa variabel penggunaan pupuk organik, pupuk anorganik dan pakan larva berada pada wilayah first component artinya variabel tersebut memiliki korelasi yang besar terhadap jumlah larva.

Upaya yang diperlukan untuk meningkatkan jumlah produksi diantaranya adanya standar tentang cara budidaya ikan koki baster, dan pembinaan kepada masyarakat tentang perlunya melaksanakan tahapan-tahapan budidaya ikan koki baster sesuai dengan cara pembenihan ikan yang baik dan ramah lingkungan. Perlu adanya penelitian lanjutan terkait budidaya ikan yang ramah lingkungan, agar tidak terjadi pencemaran lingkungan yang diakibatkan oleh kelebihan pupuk dan pakan.

\section{REFERENSI}

Bidang Perikanan Budidaya. (2015). Laporan statistik budidaya perikanan Dinas Kelautan dan Perikanan Kabupaten Sukabumi. Sukabumi: Pemda Kabupaten Sukabumi.

Effendi, M. I. (1997). Biologi Perikanan. Yogyakarta: Yayasan Pustaka Nusatama.

Fry, F. E. J. \& Hart, J.S. (2011). Cruising speed of goldfish in relation to water temperature Journal of the Fisheries Research Board of Canada, 7b(4): 169-175, https://doi.org/10.1139/f47-018.

Gupta, S., \& Banerjee, S. (2009). Food preference of goldfish (carassius auratus (linnaeus, 1758)) and its potential in mosquito control. Electronic Journal of Ichthyology, 2: 47-58.

Hafeez-ur-Rehman, M,, Iqbal, K.J., Abbas, F., Mushtaq, M.M.H., Rasool, F. \& Parveen, S. (2015). Influence of feeding frequency on growth performance and body indices of goldfish (Carrassius auratus). J Aquac Res Development, 6:336. doi:10.4172/2155-9546.1000336.

Huet, M. (1986). Texbook of fish culture, breeding and cultivation of fish.2nd. Ed. Surrey, England: Fishing News Book Ltd.

Huwoyon, G. H., Ningrum, S. \& Aditiya, N. (2011). Pembesaran ikan Baung (Hemibagrus nemurus) yang diberi pakan berbeda di kolam tanah. Berita Biologi, 10(4).

Kordi, K. M. G. (2009). Budidaya perairan. Bandung: PT. Citra Aditya Bakti.

Marbun T.P., Darma B., \& Nurmatias. (2013). Pembenihan ikan mas koki (Carrasius auratus) dengan menggunakan berbagai substrat. Program studi manajemen sumberdaya perairan Fakultas Pertanian Universitas Sumatera Utara.

Mulyadi, Usman, M. T., \& Suryani. (2010). Pengaruh frekuensi pemberian pakan yang berbeda terhadap pertumbuhan dan kelulushidupan benih ikan Silais (Ompok hypophthalmus). Berkala Perikanan Terubuk, vol. 38, No. 2, 21-40.

Murtiati. \& Yati, M. (2016). Pengelolaan kualitas air untuk budidaya ikan. Pelatihan manajemen kualitas air. Sukabumi: Pasar Ikan Cibaraja Kabupaten Sukabumi.

Pramesti, G. (2015). Kupas tuntas data penelitian dengan SPSS 22. Jakarta: Elex Media Komputindo. Kompas Gramedia.

Syamsunarno, M.B., \& Sunarno, M.TD. (2016). Budidayaikan air tawar ramah lingkungan untuk mendukung keberlanjutan penyediaan ikan bagi masyarakat, Seminar Nasional Perikanan dan Kelautan 2016, Bandar Lampung.

Tahapari, E. \& Ningrum, S. (2009). Penentuan frekuensi pemberian pakan untuk mendukung pertumbuhan benih ikan Patin Pasupati. Berita Biologi, 9(6). 693-698. 